\title{
New thermodynamic entropy calculation based approach towards quantifying the impact of eutrophication on water environment
}

\author{
Li Luo $^{\mathrm{a},}$ Nan Duan ${ }^{\mathrm{a}}$, Xiaochang C.Wang ${ }^{\mathrm{a}, *}$, Wenshan Guo ${ }^{\mathrm{b}}$, Huu Hao Ngo ${ }^{\mathrm{b}, *}$ \\ ${ }^{a}$ International Science \& Technology Cooperation Center for Urban Alternative Water Resources \\ Development, Key Lab of Northwest Water Resource, Environment and Ecology, MOE, Engineering \\ Technology Research Center for Wastewater Treatment and Reuse, Shaanxi Province, Key Lab of \\ Environmental Engineering, Shaanxi Province, Xi'an University of Architecture and Technology, No. 13, \\ Yanta Road, Xi'an 710055, China \\ ${ }^{b}$ School of Civil and Environmental Engineering, Faculty of Engineering and Information Technology, \\ University of Technology, Sydney, Broadway, NSW 2007, Australia \\ *Corresponding authors.E-mail addresses:xcwang@xauat.edu.cn (X.C.Wang),h.ngo@uts.edu.au (H.H. \\ Ngo).
}

\begin{abstract}
Although the eutrophication phenomenon has been studied for a long time, there are still no quantifiable parameters available for a comprehensive assessment of its impacts on the water environment. As contamination alters the thermodynamic equilibrium of a water system to a state of imbalance, a novel method was proposed, in this study, for its quantitative evaluation. Based on thermodynamic analyses of the algal growth process, the proposed method targeted, both theoretically and experimentally, the typical algae species encountered in the water environment. By calculating the molar enthalpy of algae biomass production, the heat energy dissipated in the photosynthetic process was firstly evaluated. The associated entropy production $(\Delta S)$ in the aquatic system could be then obtained. For six algae strains of distinct molecular formulae, the heat energy consumed for the production of a unit algal biomass was found to proportionate to the mass of nitrogen $(\mathrm{N})$ or phosphorus $(\mathrm{P})$ uptake through photosynthesis. A proportionality relationship between $\Delta \mathrm{S}$ and the algal biomass with a coefficient circa $44 \mathrm{~kJ} / \mathrm{g}$ was obtained. By the principle of energy conservation, the heat energy consumed in the process of algae biomass production is stored in the algal biomass. Furthermore, by measuring the heat of combustion of mature algae of Microcystis flos-aquae, Anabaena flos-aquae, and Chlorella vulgaris, the proportionality relationships between the heat energy and the $\mathrm{N}$ and $\mathrm{P}$ contents were validated experimentally at $90 \%$ and $85 \%$ confidence levels, respectively. As the discharge of excess $\mathrm{N}$ and $\mathrm{P}$ from domestic wastewater treatment plants is usually the main cause of eutrophication, the proposed impact assessment approach estimates that for a receiving water body, the $\Delta \mathrm{S}$ due to a unit mass of $\mathrm{N}$ and $\mathrm{P}$ discharge is $268.9 \mathrm{~kJ} / \mathrm{K}$ and $1870.1 \mathrm{~kJ} / \mathrm{K}$, respectively. Consequently, $\mathrm{P}$ discharge control would be more important for environmental water protection.
\end{abstract}

Keywords: Nutrients; Photosynthesis; Entropy production; Water environment

\section{Introduction}

Eutrophication associated with nutrients in the effluent from wastewater treatment plants (WWTPs) has become a serious problem in aquatic environments (Cai et al., 2013). Of the many nutrients required for plant growth, inorganic nitrogen $(\mathrm{N})$ and phosphorus $(\mathrm{P})$ are known to limit 
the growth of phytoplanktons, and so their input and enrichment in water are the main factors inducing eutrophication (Statham, 2012). It has been demonstrated that the potential eutrophication impact of WWTPs is mainly related to the discharge of sewage effluent to water bodies, especially the $\mathrm{N}$ and $\mathrm{P}$ content in sewage effluent (Gallego et al., 2008). Secondary effluent from WWTPs still contains nutrients, with total N (TN) and total P (TP) concentrations ranging from 15 to $35 \mathrm{mg} \mathrm{N} / \mathrm{L}$ and 4 to $10 \mathrm{mg} \mathrm{P} / \mathrm{L}$, respectively (Carey et al., 2013). The eutrophication threshold for $\mathrm{N}$-limited aquatic systems is $0.50-1.00 \mathrm{mg} \mathrm{N} / \mathrm{L}$, and that for Plimited systems is $0.02-0.10 \mathrm{mg} \mathrm{P} / \mathrm{L}$ (Lin et al., 2008). Moreover, inorganic $\mathrm{N}$ and $\mathrm{P}$ play significant roles in algal cell growth and metabolism because $\mathrm{N}$ is needed for protein synthesis, while $\mathrm{P}$ is required for DNA, RNA, and energy transfer (Conley et al., 2009; Cai et al., 2013). Thus, the release of excess N and P from municipal WWTP effluent into the environment leads to eutrophication, which consequently, cause excessive algal growth.

Cultural eutrophication, the process by which a freshwater ecosystem becomes over-enriched with dissolved nutrients as a result of point and nonpoint source pollutant inputs, can cause environmental effects that are directly related to algal proliferation (Strokal et al., 2017). Nevertheless, although the eutrophication phenomenon has been studied for long, there is still no quantifiable parameters available for a comprehensive assessment of its impact on the water environment. The environmental impact of excessive nutrients discharge into a water body can be measured as eutrophication, but the substantive issue is the change of the thermodynamic equilibrium conditions of the water body. A water body in a healthy state is considered as an ecosystem in chemical and thermodynamic equilibrium (Diaz-Mendez et al., 2013). When secondary effluent containing excess $\mathrm{N}$ and $\mathrm{P}$ is discharged into the water body, the original state of thermodynamic equilibrium will be altered. If the nutrient load exceeds the carrying capacity of the water body, it can cause eutrophication due to a sharp increase in algal growth. In this case, the water body is no longer in equilibrium, and the thermodynamic state shifts from a balanced to an imbalanced status. Thus, by analyzing the thermodynamic state of the water body and by identifying a thermodynamic indicator to evaluate this state quantitatively, the environmental impact of excess nutrients discharge to the water body can be quantitatively assessed. The disequilibrium of a system can become irreversible as a result of fluctuations in physical and chemical factors, which destabilize the system and result in the production of entropy (Lucia, 2012). From a thermodynamic standpoint, the entropic distance from thermodynamic equilibrium is the key quantity to consider when describing the state of an ecosystem (Ludovisi, 2014). According to the second law of thermodynamics, entropy quantifies the system's evolutionary course towards increasingly more probable states, while entropy production describes its irreversibility. Moreover, the entropy production and the export of that entropy are considered to belong to the most important controlling factors of the ecosystem (Mauersberger, 1996). Thus, entropy production could represent the basis of a new approach to the impact assessment and be used as a promising indicator to evaluate eutrophication caused by excessive nutrients discharge quantitatively. Thermodynamics has some important features that allow it to be used to assess the impact of pollutants. First, the thermodynamic approach provides a universal language to compare different pollutants, which overcomes problems due to the individual characteristics of pollutants (Ludovisi and Poletti, 2003). Second, it provides a general theoretical framework based on the state of a system, which overcomes the problems of subjectivity. 
In using entropy production as a tool for water environmental analysis, the basic thermodynamics approach, as proposed in a previous study (Aoki, 1983), was to calculate entropy production on the earth by using balance equations for radiation energy and entropy. The method was used to evaluate the annual entropy production from entropy fluxes associated with direct, diffuse, and reflected shortwave radiation in lakes (Aoki, 1987). In surface waters, it was considered that chemical, physical, and organic activities would be supported by chemical energy released by decomposition of macro-molecules in organisms by respiration (Aoki, 2006a; Aoki, 2006b). Entropy production was successfully evaluated by using data of biomass and respiration in trophic compartments in aquatic food webs (Aoki, 2008). Another study focused on the correlation between entropy production indices and Carlson's trophic state index for several lake ecosystems (Ludovisi and Poletti, 2003). The data reported in Ludovisi and Poletti (2003) were used to calculate biotic and abiotic entropy production in lake ecosystems (Ludovisi, 2004). Later, the ratio between the entropy produced and the stored exergy, which is the maximum amount of useful work produced, by the biological component of an ecosystem was proposed as a thermodynamic indicator for elucidating the evolution of ecological systems (Ludovisi et al., 2005) and the developmental state of lake communities (Ludovisi, 2006). Furthermore, the net radiative entropy exchange showed a significant correlation with phytoplankton successional traits in the studied lakes (Ludovisi, 2012), and so entropy production was considered to indicate the extent of biological activity in a lake (Ludovisi, 2014). Similar principles have been applied to assess biological developmental states (Martyushev and Seleznev, 2006), the state and sustainability of ecosystems (Chakrabarti and Ghosh, 2009; Meysman and Bruers, 2010), the reduction and excessive consumption of resources (Diaz-Mendez et al., 2013), the utilization efficiency of natural resources (Samiei and Fröling, 2014), and the overall activity of ecosystems (Lin, 2015). Most of the studies as mentioned above have focused on the long-term natural evolution of the environment due to the shift in thermodynamic equilibrium conditions.

As cultural eutrophication is irreversible processes, they will result in entropy production according to the second law of thermodynamics. Therefore, more sophisticated thermodynamic analyses may be needed to estimate the impact of eutrophication due to excess $\mathrm{N}$ and $\mathrm{P}$ discharge on the receiving water body. However, there is no calculation method to quantitatively evaluate this impact based on thermodynamic principles. Considering that the impact of any contamination is the change in state of a water system from thermodynamic equilibrium to imbalance, this study presents, for the first time, thermodynamic analyses of algal growth processes. For quantitative assessment of the impact of eutrophication due to the discharge of excess $\mathrm{N}$ and $\mathrm{P}$, we first establish a method for calculating entropy production in aquatic systems caused by nutrient pollution, and then experimentally validate and apply this method to a case study.

\section{Theoretical calculation and experimental methods}

\subsection{Theoretical calculation methods}

\subsubsection{Calculation of standard molar enthalpy of formation of algae $\Delta_{f} H_{\text {algae }}$}

The main causes of eutrophication in natural waters have been identified as $\mathrm{N}$ in the forms of ammonium-N $\left(\mathrm{N}-N H_{4}{ }^{+}\right)$and nitrate-N $\left(\mathrm{N}-N O_{3}{ }^{-}\right)$, and $\mathrm{P}$ in the form of phosphates $\left(\mathrm{PO}_{4}{ }^{3}\right)$ 
(Zamparas and Zacharias, 2014). In secondary WWTP effluents, $\mathrm{N}$ occurs mainly as $\mathrm{NH}_{4}{ }^{+}$and $\mathrm{NO}_{3}{ }^{-}$, while $\mathrm{P}$ is predominantly in the form of $\mathrm{PO}_{4}{ }^{3-}$. When the secondary effluent containing excess nutrients is discharged into a water body, the worst condition is that all of the $\mathrm{N}$ and $\mathrm{P}$ exist in the most biologically available forms. The most biologically accessible form of $\mathrm{N}$ is $\mathrm{N}$ $\mathrm{NH}_{4}{ }^{+}$, because of its reduced state and energetically favorable assimilation. Thus, to assess the impact of eutrophication, $\mathrm{NH}_{4}{ }^{+}$and $\mathrm{PO}_{4}{ }^{3-}$ were used as the $\mathrm{N}$ and $\mathrm{P}$ sources for algal photosynthesis, respectively. The essential elements of carbon $(\mathrm{C})$, hydrogen $(\mathrm{H})$, oxygen $(\mathrm{O}), \mathrm{N}$ and $\mathrm{P}$, which provide the atomic-level skeletons for biomolecules constitute over $95 \%$ of phytoplankton by mass. So, a general molecular formula of $\mathrm{C}_{\mathrm{x}} \mathrm{H}_{\mathrm{y}} \mathrm{O}_{\mathrm{z}} \mathrm{N}_{\mathrm{t}} \mathrm{P}_{\mathrm{m}}$ can be utilized to represent the algal biomass (Beal et al., 2012; Moore et al., 2013). Based on the overall process of photosynthesis, the algae growth equation based on carbon dioxide $\left(\mathrm{CO}_{2}\right)$, water $\left(\mathrm{H}_{2} \mathrm{O}\right), \mathrm{NH}_{4}{ }^{+}$and $\mathrm{PO}_{4}{ }^{3-}$ could be written as follows (Manahan, 2009):

$$
\begin{aligned}
& x \mathrm{CO}_{2}+\frac{(y-3 t-3 m)}{2} \mathrm{H}_{2} \mathrm{O}+t \mathrm{NH}_{4}^{+}+\mathrm{mPO}_{4}^{3-} \rightarrow \mathrm{C}_{x} \mathrm{H}_{y} \mathrm{O}_{z} \mathrm{~N}_{t} \mathrm{P}_{m} \\
& +\left(x+\frac{y}{4}-\frac{z}{2}+\frac{5 m}{4}-\frac{3 t}{4}\right) \mathrm{O}_{2}+(t-2 m) \mathrm{H}^{+}
\end{aligned}
$$

where $\mathrm{x}, \mathrm{y}, \mathrm{z}, \mathrm{t}$ and $\mathrm{m}$ are the molar numbers of the elements $\mathrm{C}, \mathrm{H}, \mathrm{O}, \mathrm{N}$ and $\mathrm{P}$ forming the algal biomass, respectively; $\mathrm{CO}_{2}, \mathrm{H}_{2} \mathrm{O}, \mathrm{NH}_{4}{ }^{+}, \mathrm{PO}_{4}{ }^{3-}, \mathrm{C}_{\mathrm{x}} \mathrm{H}_{\mathrm{y}} \mathrm{O}_{\mathrm{z}} \mathrm{N}_{\mathrm{t}} \mathrm{P}_{\mathrm{m}}, \mathrm{O}_{2}$ and $\mathrm{H}^{+}$are the carbon dioxide, water, ammonium nitrogen, phosphates, algal biomass, oxygen and hydrogen ion, respectively.

For a reaction under constant pressure, the heat of the reaction $(\Delta \mathrm{Q})$ is numerically equal to the enthalpy change of the reaction $\left(\Delta_{\mathrm{r}} \mathrm{H}\right)$ (Atkins and de Paula, 2002). Thus, the total quantity of heat energy exchanged with the environment as algal growth proceeds from its initial to its final state at constant temperature and pressure can be determined by $\Delta_{\mathrm{r}} \mathrm{H}$, which is represented by the photosynthesis equation. The standard molar enthalpy change of the photosynthesis reaction $\Delta_{\mathrm{r}} \mathrm{H}^{0}$ $(\mathrm{kJ} / \mathrm{mol})$ resulting from an algal growth process such as that represented in Eq. (1) can be calculated as follows (Battley, 2011):

$$
\Delta_{r} H^{0}=\sum v_{\text {prod }} \Delta_{f} H_{\text {prod }}^{0}-\sum v_{\text {react }} \Delta_{f} H_{\text {react }}^{0}
$$

where, $v_{\text {prod }}$ and $v_{\text {react }}$ are the stoichiometric coefficients of each product and that of each reactant from Eq. (1), respectively; $\Delta_{f} H_{\text {prod }}{ }^{0}$ and $\Delta_{f} H_{\text {react }}{ }^{0}$ are the standard molar enthalpy of formation for each product and each reactant $(\mathrm{kJ} / \mathrm{mol})$, respectively.

If the standard molar enthalpy of formation of the reactants and products of a reaction or process are known, $\Delta_{\mathrm{r}} \mathrm{H}^{0}$ can be calculated by Eq. (2). The values of the standard molar enthalpy of formation for the various substances $\left(\Delta_{\mathrm{f}} \mathrm{H}_{\mathrm{m}}{ }^{0}\right)$ represented in Eq. (1) can be found in the thermodynamic database (Atkins and de Paula, 2002), except for the algal biomass, $\Delta_{\mathrm{f}} \mathrm{H}_{\text {algae }}$. Therefore, to obtain the heat energy of an algal growth process, it is necessary to calculate $\Delta_{\mathrm{f}} \mathrm{H}_{\text {algae. }}$

According to the combustion heat of algal biomass $\left(\Delta_{\mathrm{r}} \mathrm{H}_{\mathrm{c}}{ }^{0}\right)$, a value for $\Delta_{\mathrm{f}} \mathrm{H}_{\mathrm{algae}}$ can be indirectly calculated based on Eq. (2). The combustion reaction could be written in a general equation as follows (Battley, 1999): 


$$
\begin{aligned}
& \mathrm{C}_{x} \mathrm{H}_{y} \mathrm{O}_{z} \mathrm{~N}_{t} P_{m}+\left(x+\frac{y}{4}+\frac{5 m}{4}-\frac{z}{2}\right) \mathrm{O}_{2} \rightarrow x \mathrm{CO}_{2}+\frac{y}{2} \mathrm{H}_{2} \mathrm{O}+\frac{t}{2} \mathrm{~N}_{2} \\
& \quad+\frac{m}{4} \mathrm{P}_{4} \mathrm{O}_{10}
\end{aligned}
$$

where $\mathrm{N}_{2}$ and $\mathrm{P}_{4} \mathrm{O}_{10}$ are nitrogen gas and phosphorus pentoxide, respectively; other parameters are the same as in Eq. (1).

The method to estimate the $\Delta_{\mathrm{r}} \mathrm{H}_{\mathrm{c}}{ }^{0}$ from its elemental composition and the degree of reduction $r^{0}$ is based on the following empirical correlation (von Stockar and Liu, 1999):

$$
\begin{aligned}
& \Delta_{r} H_{c}^{0}=-115 r^{0} \\
& r^{0}=4\left(x+\frac{y}{4}+\frac{5 m}{4}-\frac{z}{2}\right)
\end{aligned}
$$

where, $r^{0}$ is the degree of reduction; $\mathrm{x}, \mathrm{y}, \mathrm{z}$, and $\mathrm{m}$ are the same as in Eq. (1).

For an algal biomass with known molecular formula, its combustion reaction is assumed to be represented by Eq. (3), and then $\Delta_{\mathrm{r}} \mathrm{H}_{\mathrm{c}}{ }^{0}$ can be obtained by Eqs. (4) and (5). Based on $\Delta_{\mathrm{r}} \mathrm{H}_{\mathrm{c}}{ }^{0}$, $\Delta_{\mathrm{f}} \mathrm{H}_{\text {algae }}$ can be calculated from Eq. (2) with the stoichiometric coefficient for each component involved in Eq. (3) and the $\Delta_{\mathrm{f}} \mathrm{H}_{\mathrm{m}}{ }^{0}$ for each reactant and product obtained from the thermodynamic database (Atkins and de Paula, 2002)

\subsubsection{Entropy production calculation based on photosynthesis}

Entropy production $(\Delta S)$ is the entropy produced by irreversible processes occurring within a system. For open systems, the variation in entropy production can be expressed as follows (Svirezhev, 2000):

$$
d S(t)=d Q(t) / T(t)
$$

where, $\mathrm{dQ}(\mathrm{t})$ is the heat energy dissipation caused by irreversible processes within the system $(\mathrm{kJ})$ and $\mathrm{T}(\mathrm{t})$ is the absolute temperature $(\mathrm{K})$.

For a chemical/biochemical reaction under constant temperature, the entropy production of the reaction can be expressed as follows (Battley, 1999):

$$
\Delta S=\Delta Q / T
$$

where, $\Delta \mathrm{S}$ is the entropy production $(\mathrm{kJ} / \mathrm{K}) ; \Delta \mathrm{Q}$ is the heat energy heat energy consumption in the reaction $(\mathrm{kJ})$; and $\mathrm{T}$ is the absolute temperature $(\mathrm{K})$.

The difference between the maximum and minimum temperatures at averaged depth is small compared to the absolute temperature scale in a water body. Therefore, it can be approximated that the temperature of the water body is about constant. Thus, entropy production can be calculated by dividing the dissipation function by the annual average temperature of the water body (Aoki, 2006a). The algal growth process, which is represented as photosynthesis in surface water, is assumed to occur under constant pressure (atmospheric pressure, if the influence of water depth is ignorable). Therefore, the enthalpy change of photosynthesis $\left(\Delta_{\mathrm{r}} \mathrm{H}\right)$ is equal to $\Delta \mathrm{Q}$. 
The relationship between $\Delta_{\mathrm{r}} \mathrm{H}$ and the standard molar enthalpy change $\Delta_{\mathrm{r}} \mathrm{H}^{0}$ is $\Delta_{\mathrm{r}} \mathrm{H}=\mathrm{n} \times \Delta_{\mathrm{r}} \mathrm{H}^{0}$. Using $\Delta_{\mathrm{r}} \mathrm{H}$ instead of $\Delta \mathrm{Q}$ in Eq. (7), the entropy production of nutrient uptake by algae can be calculated as follows:

$$
\Delta S_{\mathrm{i}}=\frac{\Delta_{r} H_{\mathrm{i}}^{0} \times n}{T_{w}}=\frac{\Delta Q_{\mathrm{i}} \times \mathrm{m}}{T_{w}}
$$

where, $\Delta \mathrm{S}_{\mathrm{i}}$ is the entropy production of algal growth due to nutrient discharge $(\mathrm{kJ} / \mathrm{K}) ; \Delta_{\mathrm{r}} \mathrm{H}_{\mathrm{i}}{ }^{0}$ is the enthalpy change of photosynthesis per $1 \mathrm{~mol}$ of nutrient taken up by algae $(\mathrm{kJ} / \mathrm{mol})$; $\mathrm{n}$ is the molar number of nutrient taken up by algae (mol); $\Delta \mathrm{Q}_{\mathrm{i}}$ is the heat energy consumption per unit mass of nutrient taken up by algae $(\mathrm{kJ} / \mathrm{g}) ; \mathrm{m}$ is the mass of nutrient taken up by algae $(\mathrm{g})$; and $\mathrm{T}_{\mathrm{w}}$ is the average water temperature $(\mathrm{K})$.

\subsection{Experimental procedure}

\subsubsection{Algal strains and culture conditions}

Strains of the freshwater algae Microcystis flos-aquae (FACHB-1028), Anabaena flos-aquae (FACHB-245), and Chlorella vulgaris (FACHB-8) were purchased from the Freshwater Algae Culture Collection of the Institute of Hydrobiology (FACHB-Collection), Chinese Academy of Sciences (Wuhan, China). M. flos-aquae and C. vulgaris were cultured in BG-11 medium, while A. flos-aquae was cultured in SE medium (Bristol's solution). The three algae strains were cultured in $200 \mathrm{~mL}$ autoclaved medium in $500 \mathrm{~mL}$ conical flasks in a light incubator under the following conditions: illumination intensity $=3000 \mathrm{~lx}$, light/dark interval $=14 \mathrm{~h} / 10 \mathrm{~h}$, temperature $=25 \pm 1{ }^{\circ} \mathrm{C}$, and artificial intermittent shaking of three times per day. After inoculation, the three algae strains were cultured as described above and harvested in the logarithmic phase after 15-20 days when the stock suspension reached a cell density of $10^{9}$ cells/L, as measured using a photomicroscope (Eclipse 90i, Nikon, Tokyo, Japan). The algae were collected by centrifugation at $4000 \mathrm{rpm}$ for $30 \mathrm{~min}$ in a refrigerated centrifuge (Sorvall RC 6 Plus, Thermo Scientific, Waltham, MA, USA) and freeze-dried using a vacuum freeze drier (FD1A-50, Boyikang Corp., Beijing, China) for storage in a desiccator at room temperature till further use for biomass composition determination and combustion heat measurements.

\subsubsection{Experimental analyses of algae}

The percentages of $\mathrm{C}, \mathrm{H}, \mathrm{N}$, and $\mathrm{O}$ in the total algal biomass were determined after complete combustion of each sample using a CHNS/O element analyzer (Vario EL III, Elementar Analysensysteme GmbH, Hanau, Germany). Other elements in the algal biomass samples were analyzed using an X-ray fluorescence (XRF) spectrometer (S4 Pioneer, Bruker Co., Karlsruhe, Germany). For the $\mathrm{CHN} / \mathrm{O}$ analysis, freeze-dried samples were weighed in pre-cleaned tin/silver capsules, placed inside the auto-sampler at a preset time, and then dropped into an oxidation/reduction reactor kept at a temperature of $900-1000{ }^{\circ} \mathrm{C}$. For the XRF analysis, the freeze-dried sample were prepared as pressed powder pellets of $23 \mathrm{~mm}$ in diameterand then were kept in desiccators for at least $24 \mathrm{~h}$ to get rid of the moisture contents. The calorimetric values of the freeze-dried samples were measured by bomb calorimeter (SDC 5015, Sundy Corp., Changsha, China) according to the ISO 1928:2009 standard (ISO, 2009). The experimental set-up of the combustion bomb calorimeter is schematically shown in Fig. 1. After temperature 
equilibrium and preparation, the calorimeter was calibrated with benzoic acid of $99.999 \%$ purity, which has a standard heat of combustion of $-26,456 \mathrm{~J} / \mathrm{g}$ at $298.15 \mathrm{~K}$. The initial temperature and oxygen pressure of the combustion reaction were regulated to $298.15 \pm 0.01 \mathrm{~K}$ and $2.5 \mathrm{MPa}$, respectively. The calibrated energy equivalent of the calorimeter was $18,604.99 \pm 8.14 \mathrm{~J} / \mathrm{K}$ with a precision of $4.38 \times 10^{-4}$. Subsequently, the heat of combustion of samples were measured using the calorimeter, which had been calibrated with benzoic acid. All experiments were carried out in triplicate.

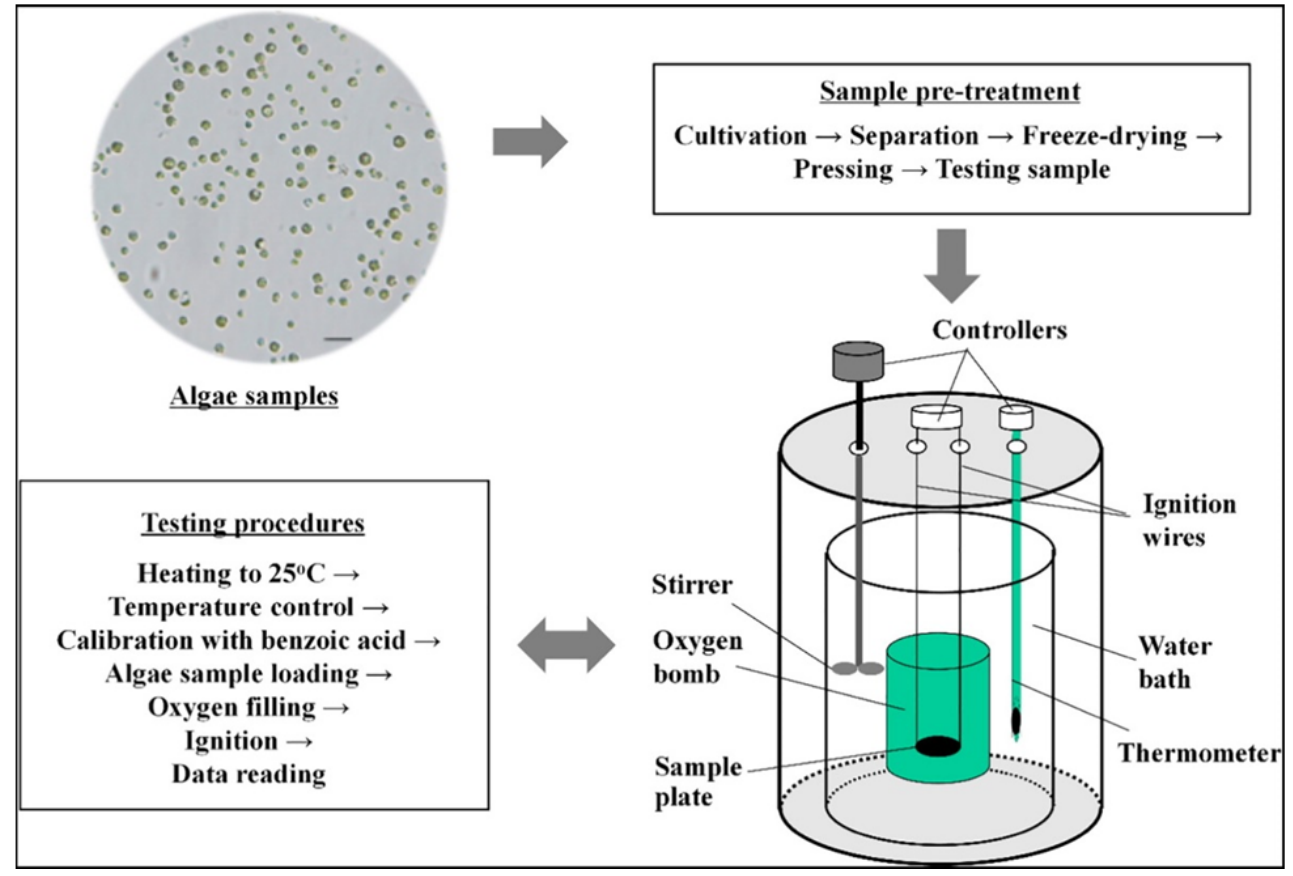

Fig. 1. Schematic of the experimental procedures for bomb calorimeter analysis of algae

\section{Results and discussion}

\subsection{Calculation of theoretical entropy production by algal growth due to nutrients discharge}

For an algal biomass with known molecular formula, the following parameters were firstly calculated according to the theoretical consideration presented in section 2.1.1: the heat of combustion of the algal biomass $\left(\Delta_{\mathrm{r}} \mathrm{H}_{\mathrm{c}}{ }^{0}\right)$, the standard molar enthalpy of algae formation $\left(\Delta_{\mathrm{f}} \mathrm{H}_{\text {algae }}\right)$, and the standard molar enthalpy change of the photosynthesis reaction $\left(\Delta_{\mathrm{r}} \mathrm{H}^{0}\right)$. Subsequently, the heat energy consumption per unit mass of $\mathrm{N}$ and $\mathrm{P}$ uptake by the algal biomass when $\mathrm{N}$ is the limiting factor $\left(\Delta \mathrm{Q}_{\mathrm{N}}\right)$, and $\mathrm{P}$ is the limiting factor $\left(\Delta \mathrm{Q}_{\mathrm{P}}\right)$, respectively, were obtained.

Based on the molecular formulae of the six different algal biomasses available in the literature (Sansawa and Endo, 2004; Muñoz and Guieysse, 2006; Chisti, 2007; Manahan, 2009; Beal et al., 2012; Muñoz et al., 2015), the values of $\Delta_{\mathrm{r}} \mathrm{H}_{\mathrm{c}}{ }^{0}, \Delta_{\mathrm{f}} \mathrm{H}_{\text {algae }}, \Delta_{\mathrm{r}} \mathrm{H}^{0}, \Delta \mathrm{Q}_{\mathrm{N}}$, and $\Delta \mathrm{Q}_{\mathrm{P}}$ were calculated as shown in Table 1. Overall, the values of $\Delta Q_{N}$ and $\Delta Q_{P}$ were found to increase with the ratios of $\mathrm{C}: \mathrm{N}$ and C:P. Fig. 2 shows the linear relationships of $\mathrm{w}_{\mathrm{N}}-\Delta \mathrm{Q}_{\mathrm{N}}$ and $\mathrm{w}_{\mathrm{P}}-\Delta \mathrm{Q}_{\mathrm{P}}$ using the calculated data for the six algal biomass formulae (Table 1), where $\mathrm{w}_{\mathrm{N}}$ and $\mathrm{w}_{\mathrm{P}}$ are percentages of $\mathrm{N}$ and $\mathrm{P}$ masses, respectively. $\Delta \mathrm{Q}_{\mathrm{N}}$ and $\Delta \mathrm{Q}_{\mathrm{P}}$ can then be obtained as follows: 


$$
\begin{aligned}
& \Delta Q_{N}=560.82-33.555 w_{N} \\
& \Delta Q_{P}=3992.3-1652.8 w_{P}
\end{aligned}
$$

Table 1. Key parameters for calculating theoretical entropy production by six algal biomasses of

\begin{tabular}{|c|c|c|c|c|c|c|}
\hline $\begin{array}{l}\text { Molecular formula of algal } \\
\text { biomass }\end{array}$ & Reference & $\begin{array}{c}\Delta_{\mathbf{r}} \mathbf{H}_{\mathrm{c}}{ }^{\mathbf{0}} \stackrel{\mathrm{a}}{(\mathrm{kJ} / \mathbf{m o l})} \\
\end{array}$ & $\begin{array}{l}\Delta_{\mathrm{f}} \mathrm{H}_{\text {algae }} \\
(\mathrm{kJ} / \mathrm{mol})\end{array}$ & $\begin{array}{c}\Delta_{\mathrm{r}} \mathrm{H}^{\mathbf{0 c}} \\
(\mathrm{kJ} / \mathrm{mol})\end{array}$ & $\begin{array}{l}\Delta \mathbf{Q}_{N}{ }^{\mathrm{d}} \\
(\mathrm{kJ} / \mathrm{g})\end{array}$ & $\begin{array}{l}\Delta Q_{P^{e}} \\
(k J / g)\end{array}$ \\
\hline $\mathrm{C}_{106} \mathrm{H}_{181} \mathrm{O}_{45} \mathrm{~N}_{15} \mathrm{P}$ & (Beal et al., 2012) & $-59,800$ & -8524.62 & $55,473.68$ & 264.16 & 1789.47 \\
\hline $\mathrm{C}_{5.7} \mathrm{H}_{9.8} \mathrm{O}_{2.3} \mathbf{N P}_{0.06}$ & (Manahan, 2009) & -3254.50 & -433.78 & 2965.30 & 211.81 & 1594.24 \\
\hline $\mathrm{C}_{3.96} \mathrm{H}_{7.9} \mathbf{O}_{1.875} \mathbf{N}_{0.685} \mathbf{P}_{0.0539}$ & (Sansawa and Endo, 2004) & -2329.84 & -397.66 & 2133.24 & 222.44 & 1276.70 \\
\hline $\mathrm{CH}_{1.7} \mathbf{O}_{0.4} \mathbf{N}_{0.15} \mathbf{P}_{0.0094}$ & (Muñoz and Guieysse, 2006) & -568.90 & -74.56 & 525.57 & 250.37 & 1803.61 \\
\hline $\mathrm{CH}_{1.83} \mathrm{O}_{0.48} \mathrm{~N}_{0.11} \mathbf{P}_{0.01}$ & (Chisti, 2007) & -565.80 & -96.69 & 534.39 & 347.00 & 1723.83 \\
\hline $\mathrm{CH}_{1.63} \mathrm{O}_{0.43} \mathrm{~N}_{0.14} \mathrm{P}_{0.006}$ & (Muñoz et al., 2015) & -552.00 & -78.93 & 511.23 & 260.83 & 2748.55 \\
\hline
\end{tabular}
distinct molecular formulae.

${ }^{\mathrm{a}}$ Heat of combustion of algal biomass.

${ }^{\mathrm{b}}$ Standard molar enthalpy of algae formation.

${ }^{\mathrm{c}}$ Standard molar enthalpy change of photosynthesis reaction.

${ }^{\mathrm{d}}$ Heat energy consumption per unit mass of $\mathrm{N}$ uptake by algal biomass when $\mathrm{N}$ is limiting.

${ }^{\mathrm{e}}$ Heat energy consumption per unit mass of $\mathrm{P}$ uptake by algal biomass when $\mathrm{P}$ is limiting.
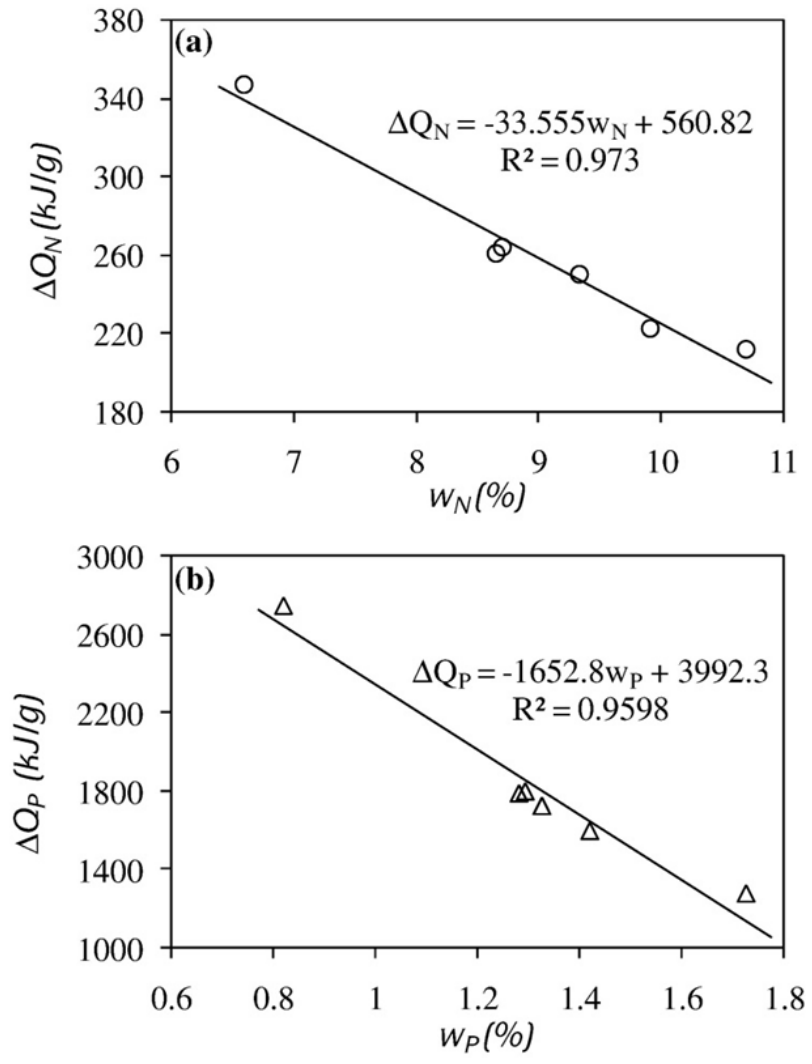

Fig. 2. Relationships between nutrient contents of algae and heat energy consumption per unit of nutrient uptake by algae (a) nitrogen (b) phosphorus 
As $\mathrm{w}_{\mathrm{N}}$ and $\mathrm{w}_{\mathrm{P}}$ are dimensionless, while the slopes and intercepts of Eqs. (9) and (10) have the dimensions of $\mathrm{kJ} / \mathrm{g}$, the dimension of $\Delta \mathrm{Q}_{\mathrm{N}}$ and $\Delta \mathrm{Q}_{\mathrm{P}}$ are also in $\mathrm{kJ} / \mathrm{g}$.

Assuming that the main components of TN and TP in the secondary effluent discharge are N$\mathrm{NH}_{4}{ }^{+}$and $\mathrm{PO}_{4}{ }^{3-}$, which are completely taken up by algal photosynthesis, the environmental impact of excess nutrients can be then quantitatively evaluated by the entropy approach. Substituting Eqs. (9) and (10) into Eq. (8), the entropy production of nutrient uptake by algae can be expressed as follows:

$$
\begin{aligned}
& \Delta S_{\mathrm{N}}=\frac{\Delta Q_{\mathrm{N}} \times \mathrm{m}}{T_{w}}=\frac{\left(560.82-33.555 w_{N}\right) \times \Delta C_{N} \times V}{T_{w}} \\
& \Delta S_{\mathrm{P}}=\frac{\Delta Q_{\mathrm{P}} \times \mathrm{m}}{T_{w}}=\frac{\left(3992.3-1652.8 w_{P}\right) \times \Delta C_{P} \times V}{T_{w}}
\end{aligned}
$$

where, $\Delta \mathrm{S}_{\mathrm{N}}$ is the entropy production of $\mathrm{N}$ uptake by algae when $\mathrm{N}$ is the limiting factor $(\mathrm{kJ} / \mathrm{K})$, $\Delta \mathrm{S}_{\mathrm{P}}$ is the entropy production of $\mathrm{P}$ uptake by algae when $\mathrm{P}$ is the limiting factor $(\mathrm{kJ} / \mathrm{K})$, $\Delta C_{N}=C_{N}-C_{N 0}$ and $\Delta C_{P}=C_{P}-C_{P 0}$ are the excess TN and TP discharge into the water body as the difference between the discharged concentration $\left(C_{N}\right.$ and $\left.C_{P}, g / \mathrm{m}^{3}\right)$ and the background concentration $\left(\mathrm{C}_{\mathrm{N} 0}\right.$ and $\left.\mathrm{C}_{\mathrm{P} 0}, \mathrm{~g} / \mathrm{m}^{3}\right)$, and $\mathrm{V}$ is the volume of the secondary effluent discharge $\left(\mathrm{m}^{3}\right)$.

In environmental assessment, the phytoplankton biomass content is usually considered as an important indicator of eutrophication. Therefore, to obtain the relationships between algal biomass content $\left(\mathrm{m}_{\mathrm{a}}\right)$ and heat energy consumption per unit of nutrient uptake by algae, the corresponding values of $\mathrm{m}_{\mathrm{a}}$ in equivalent carbon units $(\mathrm{g} \mathrm{C} / \mathrm{g})$ for the six algae with known molecular formulae (Table 1) were calculated using the equation for the photosynthesis reaction. A plot of $\Delta Q_{N}$ and $\Delta Q_{P}$ versus $m_{a}$ (Fig. 3), using the calculated data shows that the heat energy consumption tends to increase proportionally with the algal biomass content regardless of the mass of $\mathrm{N}$ or $\mathrm{P}$ uptake by the algae. The proportionality coefficients of 43.784 and $43.449 \mathrm{~kJ} / \mathrm{g}$ were obtained, respectively, for the $\Delta \mathrm{Q}_{\mathrm{N}}-\mathrm{m}_{\mathrm{a}}$ and $\Delta \mathrm{Q}_{\mathrm{P}}-\mathrm{m}_{\mathrm{a}}$ relationships. The highly similar coefficients obtained indicated that the heat energy consumption is the same for the production of $1 \mathrm{~g}$ algal biomass either due to $\mathrm{N}$ uptake or $\mathrm{P}$ uptake. If $44 \mathrm{~kJ} / \mathrm{g}$ is taken as the approximate coefficient, the total entropy production by algal growth due to nutrients uptake can be obtained following Eq. (8) as:

$$
\Delta S_{\text {biomass }}=\frac{44 m_{a}}{T_{w}}
$$

where $\Delta \mathrm{S}_{\text {biomass }}$ is the total entropy production by algal growth due to nutrient uptake $(\mathrm{kJ} / \mathrm{K}), \mathrm{m}_{\mathrm{a}}$ is the mass of algal biomass in equivalent carbon units $(\mathrm{g} \mathrm{C}), \mathrm{T}_{\mathrm{w}}$ is the average water temperature (K).

Based on the above analysis, Eqs. (11) and (12) can be used to evaluate the environmental impact of excess $\mathrm{N}$ and $\mathrm{P}$ discharge into $\mathrm{N}$-limited and $\mathrm{P}$-limited aquatic systems, respectively. 
Conversely, the environmental impact of algal growth due to nutrients discharge can be calculated by Eq. (13) in terms of $\Delta \mathrm{S}_{\text {biomass. }}$
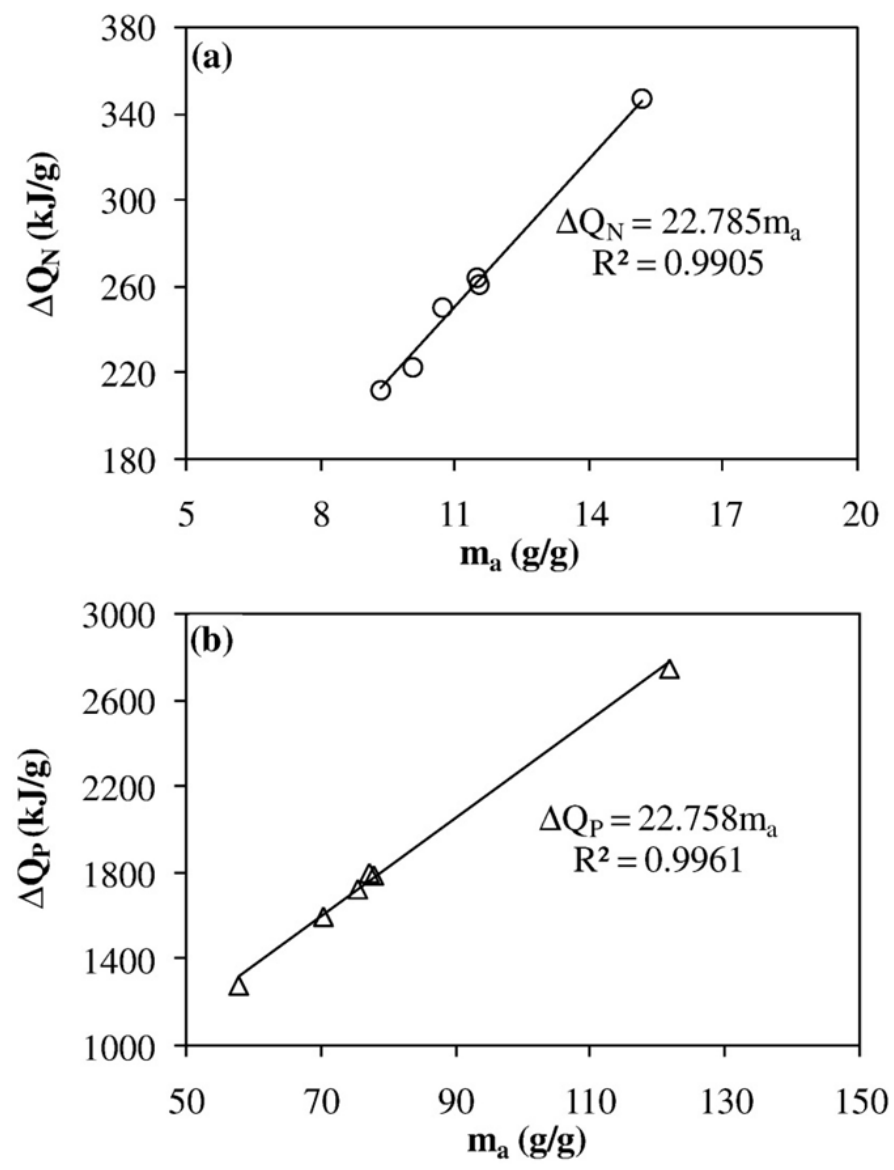

Fig. 3. Relationships between algal biomass content and heat energy consumption per unit of nutrient uptake by algae (a) nitrogen (b) phosphorus

\subsection{Experimental verification}

The molecular formula of algal biomass can be determined from the relative percentage of $\mathrm{C}, \mathrm{H}$, $\mathrm{O}, \mathrm{N}$, and $\mathrm{P}$ present in the algal biomass, while $\Delta \mathrm{Q}_{\mathrm{N}}$ and $\Delta \mathrm{Q}_{\mathrm{P}}$ can be indirectly obtained by combustion heat analysis. Thus, the relationships between nutrient contents of algae and heat energy consumption per unit of nutrient uptake by algae can be validated by elemental composition and combustion heat analysis of the algal biomass.

According to the elemental composition of the three algae strains shown in Table 2, the molecular formulae of $M$. flos-aquae, $A$. flos-aquae, and $C$. vulgaris can be written as $\mathrm{C}_{4.1} \mathrm{H}_{7.2} \mathrm{~N}_{0.75} \mathrm{O}_{1.8} \mathrm{P}_{0.02}$, $\mathrm{C}_{3.9} \mathrm{H}_{6.9} \mathrm{~N}_{0.67} \mathrm{O}_{2.0} \mathrm{P}_{0.036}$, and $\mathrm{C}_{4.2} \mathrm{H}_{7.2} \mathrm{~N}_{0.55} \mathrm{O}_{1.9} \mathrm{P}_{0.033}$, respectively. Based on the experimental data obtained for the heat of combustion $(\Delta \mathrm{Q})$, the mean for M. flos-aquae, A. flos-aquae, and $C$. vulgaris were $-23.91,-22.56$, and $-23.43 \mathrm{~kJ} / \mathrm{g}$, respectively (with relative standard deviations of $0.11 \%, 0.15 \%$, and $0.09 \%$, respectively). Using Eqs. (4) and (5), the theoretical heats of combustion of these three algae strains were calculated as $-24.00,-22.33$, and $-24.21 \mathrm{~kJ} / \mathrm{g}$, respectively, according to their molecular formulae. 
From the experimental and theoretical heats of combustion obtained for the three algae strains, $\Delta_{\mathrm{f}} \mathrm{H}_{\text {algae }}$ could be calculated by Eq. (2) on the basis of the combustion reaction. The corresponding $\Delta \mathrm{Q}_{\mathrm{N}}$ and $\Delta \mathrm{Q}_{\mathrm{P}}$ could be then calculated by Eq. (2) on the basis of the photosynthesis reaction. Table 3 shows the experimental and theoretical results of $\Delta \mathrm{Q}, \Delta \mathrm{Q}_{\mathrm{N}}$, and $\Delta \mathrm{Q}_{\mathrm{P}}$ for M. flos-aquae, $A$. flos-aquae, and C. vulgaris. It can be seen that the experimental values of $\Delta \mathrm{Q}_{\mathrm{N}}$ and $\Delta \mathrm{Q}_{\mathrm{P}}$ decreased with decreasing numbers of $\mathrm{N}$ and $\mathrm{P}$ atoms. On the other hand, as shown in Tables 2 and 3 , the experimental values of $\Delta \mathrm{Q}_{\mathrm{N}}$ and $\Delta \mathrm{Q}_{\mathrm{P}}$ decreased with increasing $\mathrm{w}_{\mathrm{N}}$ and $\mathrm{w}_{\mathrm{P}}$, respectively.

Table 2. Elemental composition of three algae strains.

\begin{tabular}{cccccc}
\hline \multirow{2}{*}{ Alga } & \multicolumn{5}{c}{ Elemental composition (wt, \%) } \\
\cline { 2 - 6 } & $\mathbf{C}$ & $\mathbf{H}$ & $\mathbf{O}$ & $\mathbf{N}$ & P \\
\hline Microcystis flos-aquae & $49.7 \pm 0.23$ & $7.19 \pm 0.17$ & $28.1 \pm 0.21$ & $10.5 \pm 0.12$ & $0.624 \pm 0.021$ \\
Anabaena flos-aquae & $46.6 \pm 0.15$ & $6.88 \pm 0.22$ & $32.5 \pm 0.25$ & $9.33 \pm 0.18$ & $1.12 \pm 0.04$ \\
Chlorella vulgaris & $49.8 \pm 0.20$ & $7.21 \pm 0.16$ & $31.0 \pm 0.19$ & $7.67 \pm 0.10$ & $1.03 \pm 0.03$ \\
\hline
\end{tabular}

Table 3. Comparison of experimental and theoretical values of algal heat of combustion $(\Delta \mathrm{Q})$ and heat energy consumption per unit of $\mathrm{N}\left(\Delta \mathrm{Q}_{\mathrm{N}}\right)$ and $\mathrm{P}\left(\Delta \mathrm{Q}_{\mathrm{P}}\right)$ uptake by three algae strains.

\begin{tabular}{|c|c|c|c|c|c|}
\hline Name and formula of alga & Index & $\begin{array}{c}\text { Experimental value } \\
(\mathrm{kJ} / \mathrm{g})\end{array}$ & $\begin{array}{l}\text { Theoretical value } \\
(\mathrm{kJ} / \mathrm{g})\end{array}$ & $\begin{array}{l}\text { Difference } \\
\text { (kJ/g) }\end{array}$ & $\begin{array}{l}\text { Relative error } \\
\text { (\%) }\end{array}$ \\
\hline \multirow{3}{*}{$\begin{array}{l}\text { Microcystis flos-aquae } \\
\left(\mathbf{C}_{4.1} \mathbf{H}_{7.2} \mathbf{N}_{0.75} \mathbf{O}_{1.8} \mathbf{P}_{0.02}\right)\end{array}$} & $\Delta \mathrm{Q}$ & -23.91 & -24.00 & 0.09 & -0.38 \\
\hline & $\Delta \mathrm{Q}_{\mathrm{N}}$ & 198.42 & 195.07 & 3.35 & 1.72 \\
\hline & $\Delta \mathrm{Q}_{\mathrm{P}}$ & 3360.40 & 2929.55 & 430.85 & 14.7 \\
\hline \multirow{3}{*}{$\begin{array}{l}\text { Anabaena flos-aquae } \\
\left(\mathrm{C}_{3.9} \mathbf{H}_{6.9} \mathbf{N}_{0.67} \mathbf{O}_{2.0} \mathbf{P}_{0.036}\right)\end{array}$} & $\Delta \mathrm{Q}$ & -22.56 & -22.33 & -0.23 & 1.03 \\
\hline & $\Delta \mathrm{Q}_{\mathrm{N}}$ & 210.60 & 233.66 & -23.06 & -9.87 \\
\hline & $\Delta \mathrm{Q}_{\mathrm{P}}$ & 1770.71 & 2075.05 & -304.34 & -14.7 \\
\hline \multirow{3}{*}{$\begin{array}{l}\text { Chlorella vulgaris } \\
\left(\mathbf{C}_{4.2} \mathbf{H}_{7.2} \mathbf{N}_{0.55} \mathbf{O}_{1.9} \mathbf{P}_{0.033}\right)\end{array}$} & $\Delta \mathrm{Q}$ & -23.43 & -24.21 & 0.78 & -3.22 \\
\hline & $\Delta \mathrm{Q}_{\mathrm{N}}$ & 275.52 & 293.72 & -18.20 & -6.20 \\
\hline & $\Delta \mathrm{Q}_{\mathrm{P}}$ & 2073.82 & 2240.33 & -166.51 & -7.43 \\
\hline
\end{tabular}

Table 3 also demonstrates the close similarity in the value of the experimental $\Delta \mathrm{Q}$ for the three algae strains to that of the theoretical calculation, with a maximum relative error of no more than $\pm 3.22 \%$. For M. flos-aquae, A. flos-aquae, and C. vulgaris, the relative error of the measured $\Delta \mathrm{Q}_{\mathrm{N}}$ was within $\pm 10 \%$. Moreover, the measured $\Delta \mathrm{Q}_{\mathrm{N}}$ values for $A$. flos-aquae and C. vulgaris were less than the corresponding calculated theoretical values. By contrast, although the differences between the measured and calculated $\Delta \mathrm{Q}_{\mathrm{P}}$ values were more pronounced, the relative error of $\Delta Q_{P}$ for the three algae strains were within $\pm 15 \%$. More specifically for $A$. flos-aquae and $C$. vulgaris, the experimental values of $\Delta \mathrm{Q}_{\mathrm{P}}$ were less than the calculated theoretical values. To understand more clearly the relative errors of the experimental results, the deviations between experimental and theoretical results of $\Delta \mathrm{Q}_{\mathrm{N}}$ and $\Delta \mathrm{Q}_{\mathrm{P}}$ for $M$. flos-aquae, A. flos-aquae, and $C$. vulgaris are plotted in Fig. 4. It is demonstrated that the $\Delta \mathrm{Q}_{\mathrm{N}}-\mathrm{W}_{\mathrm{N}}$ relationship identified in this study can be used to measure the heat change of $\mathrm{N}$ uptake by algae at a $90 \%$ confidence level. Also, the $\Delta \mathrm{Q}_{\mathrm{P}}-\mathrm{W}_{\mathrm{P}}$ relationship can be used to measure the heat change of $\mathrm{P}$ uptake by algae at a confidence level of $85 \%$. 

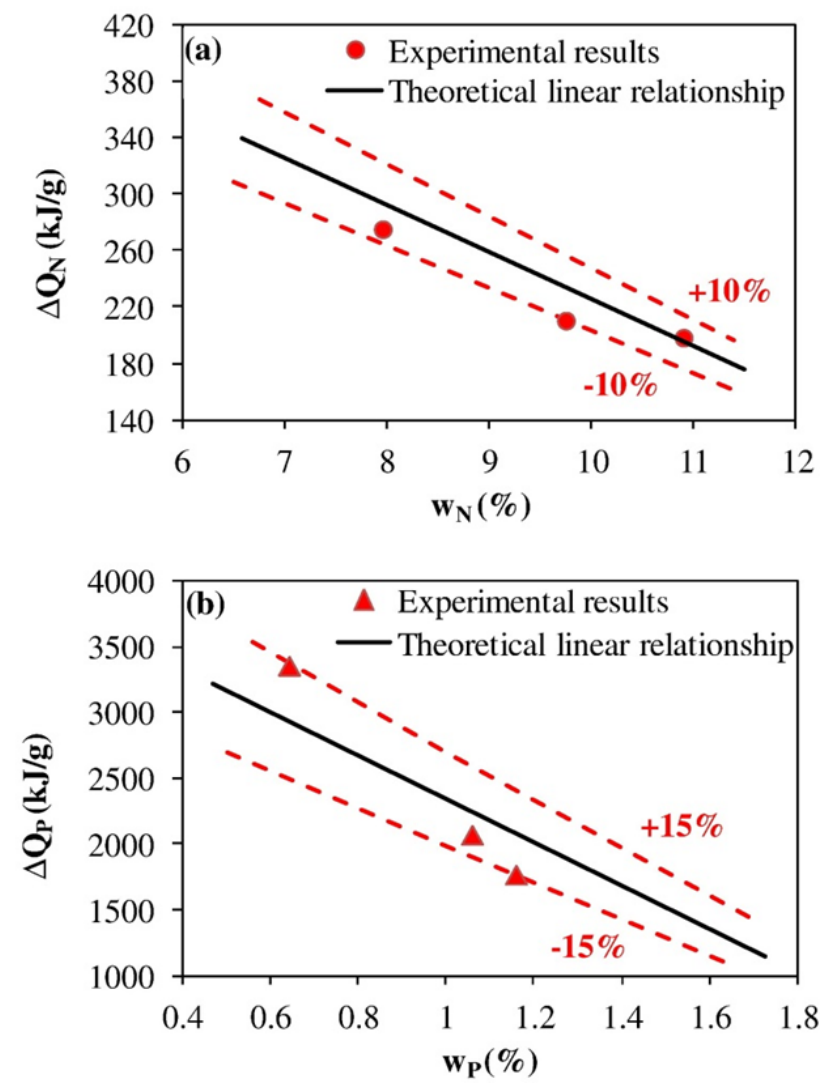

Fig. 4. Deviations between experimental and theoretical heat energy consumption per unit of nutrient uptake by three algae (a) nitrogen (b) phosphorus.

The possible reason for the deviations between experimental and theoretical results may be that the general molecular formula of algal biomass only considered the five elements of $\mathrm{C}, \mathrm{H}, \mathrm{O}, \mathrm{N}$ and $\mathrm{P}$, without considering the influence of other elements and the actual molecular structure of algae in the whole analysis. Furthermore, the structure of the $\mathrm{P}$ element in algal cells may be more complex than that of $\mathrm{N}$, leading to larger relative errors for $\Delta \mathrm{Q}_{\mathrm{P}}$. It is reported that in addition to the five elements, other elements such as $\mathrm{Ca}, \mathrm{Mg}, \mathrm{Fe}, \mathrm{Zn}, \mathrm{Cu}, \mathrm{Mn}$, etc. were also detected in algal biomass (Hognon et al., 2014; Gubelit et al., 2016). However, the essential elements of $\mathrm{C}, \mathrm{H}, \mathrm{O}, \mathrm{N}$ and $\mathrm{P}$ which provide the atomic-level skeletons for biomolecules constitute over $95 \%$ of phytoplankton by mass (Moore et al., 2013). Furthermore, although the molecular structures of specific strains is not considered, the elemental composition of $\mathrm{C}_{\mathrm{x}} \mathrm{H}_{\mathrm{y}} \mathrm{O}_{\mathrm{z}} \mathrm{N}_{\mathrm{t}} \mathrm{P}_{\mathrm{m}}$ for algae has mostly been reported for photosynthesis analysis (Manahan, 2009), studies on algal-bacterial processes for the treatment of hazardous contaminants (Muñoz and Guieysse, 2006), thermodynamic analysis of algal biocrude production (Beal et al., 2012) and photosynthetic biogas upgrading processes (Muñoz et al., 2015). Nonetheless, experimental results showed a relative error of $\Delta \mathrm{Q}$ of less than $3.22 \%$, and so the stoichiometric formula of $\mathrm{C}_{\mathrm{x}} \mathrm{H}_{\mathrm{y}} \mathrm{O}_{\mathrm{z}} \mathrm{N}_{\mathrm{t}} \mathrm{P}_{\mathrm{m}}$ can adequately represent the main characteristics of algae, especially the thermodynamic characteristics. Therefore, this approach based on thermodynamic entropy calculation is valid for quantitative impact assessment of algal growth caused by nutrient pollution.

\subsection{Application of entropy approach in a case study}


In China, the high concentration of nutrients ( $\mathrm{N}$ and $\mathrm{P}$ ) in the effluent from WWTPs often presents a major environmental problem. Nutrient fluxes to surface waters induces eutrophication and subsequently, causes rapid algal growth, which, in turn, results in a deterioration of water quality and severe environmental impacts to the water body. Upgrading of WWTP may be necessary to meet the stricter future effluent quality requirements for nutrients. China's national standard for WWTPs effluents is the Discharge Standard of Pollutants for Municipal WWTP (GB 18918-2002), which categorizes WWTPs effluents into Class 1A, Class 1B, Class 2 and Class 3, of which Class $1 \mathrm{~A}$ is the highest quality and Class 3 is the lowest. At present, as for WWTPs in China, the most popular effluent standard is that of Class 1B (Jin et al., 2014). As the water environment quality becomes increasingly degraded, many WWTPs should upgrade to meet higher effluent requirements. In this case, WWTPs designed for the class $1 \mathrm{~B}$ standard need to upgrade to class $1 \mathrm{~A}$.

To evaluate the effect of a WWTP upgrade on nutrient loading to a receiving water body, the effluent quality of Class IB for an existing WWTP (Case 1) and the effluent quality of Class IA for the upgraded WWTP (Case 2) were considered. For the quality of the receiving water body to conform to the Grade V standard, which is mainly applicable to the lakes for agricultural use and landscape requirement, the background $\mathrm{TN}$ and $\mathrm{TP}$ concentration can be obtained from China's surface water environmental quality standard (GB 3838-2002). The WWTP effluents and receiving water quality for the two cases scenarios are shown in Table 4.

Table 4. Concentrations of nutrient parameters in case study WWTP effluents and receiving water.

\begin{tabular}{|c|c|c|c|c|}
\hline Case & Parameter & $\begin{array}{c}\text { Concentrations }(\mathrm{mg} / \mathrm{L}) \text { in WWTP } \\
\text { effluent }(C)\end{array}$ & $\begin{array}{c}\text { Concentrations }(\mathrm{mg} / \mathrm{L}) \text { in receiving } \\
\text { water }\left(C_{0}\right)\end{array}$ & $\begin{array}{c}\Delta C=C- \\
C_{0}\end{array}$ \\
\hline \multirow{2}{*}{1} & $\begin{array}{l}\text { Total nitrogen } \\
\text { (TN) }\end{array}$ & e & 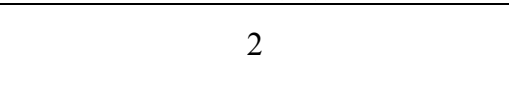 & 18 \\
\hline & $\begin{array}{l}\text { Total phosphorus } \\
\text { (TP) }\end{array}$ & 1 & 0.2 & 0.8 \\
\hline \multirow{2}{*}{2} & $\begin{array}{l}\text { Total nitrogen } \\
\text { (TN) }\end{array}$ & 15 & 2 & 13 \\
\hline & $\begin{array}{l}\text { Total phosphorus } \\
\text { (TP) }\end{array}$ & 0.5 & 0.2 & 0.3 \\
\hline
\end{tabular}

The case study was conducted for the discharge per $10,000 \mathrm{~m}^{3}\left(\mathrm{~V}=10,000 \mathrm{~m}^{3}\right)$ of secondary effluent into the receiving water bodies. For the convenience of calculation, an algae molecular formula of $\mathrm{C}_{106} \mathrm{H}_{181} \mathrm{O}_{45} \mathrm{~N}_{15} \mathrm{P}$, is assumed, and average water temperature was set at $\mathrm{T}_{\mathrm{w}}=298.15 \mathrm{~K}$ $\left(25^{\circ} \mathrm{C}\right)$. By using Eqs. (11) and (12), when either $\mathrm{N}$ or $\mathrm{P}$ is the limiting factor, the entropy production due to excess discharge of $\mathrm{TN}\left(\Delta \mathrm{S}_{\mathrm{N}}\right)$ or $\mathrm{TP}\left(\Delta \mathrm{S}_{\mathrm{P}}\right)$ for each scenario were obtained.

As shown in Fig. 5 and Table 4, for both the existing WWTP (Case 1) and the upgraded WWTP (Case 2), the concentrations of TN were 20 times and 30 times higher than that of TP, respectively. Moreover, $\Delta S_{N}$ was 3 times and 6 times greater than $\Delta S_{P}$, respectively. A possible reason for the larger $\Delta \mathrm{S}_{\mathrm{N}}$ values is that either the concentrations of TN are rather high or that not all the $\mathrm{TN}$ are in the form of $\mathrm{NH}_{4}{ }^{+}$, or both. By comparing Case 1 and Case 2, when TN concentrations decreased from $20 \mathrm{mg} / \mathrm{L}$ (Class 1B standard) to $15 \mathrm{mg} / \mathrm{L}$ (Class 1A standard), the values of $\Delta \mathrm{S}_{\mathrm{N}}$ reduced by $4.5 \times 10^{4} \mathrm{~kJ} / \mathrm{K}$. In contrast, when TP concentrations decreased from 
$1 \mathrm{mg} / \mathrm{L}$ (Class 1B standard) to $0.5 \mathrm{mg} / \mathrm{L}$ (Class $1 \mathrm{~A}$ standard), the values of $\Delta \mathrm{S}_{\mathrm{p}}$ reduced by $3.1 \times 10^{4} \mathrm{~kJ} / \mathrm{K}$. Overall, upgrading of the studied WWTP from Class 1B to Class 1A reduce the $\Delta \mathrm{S}_{\mathrm{N}}$ and $\Delta \mathrm{S}_{\mathrm{P}}$ by $27.8 \%$ and $62.5 \%$, respectively. Therefore, the effect of improving the TP effluent quality from Class IB to Class IA was remarkable. Furthermore, reducing the TN and TP by $1 \mathrm{mg} / \mathrm{L}, \Delta \mathrm{S}_{\mathrm{N}}$ and $\Delta \mathrm{S}_{\mathrm{P}}$ were correspondingly reduced by $9.0 \mathrm{~kJ} / \mathrm{K}$ and $62.7 \mathrm{~kJ} / \mathrm{K}$, respectively. The reduction of $\Delta \mathrm{S}$ implies less energy dissipation in the form of waste heat, which consequently, results in a reduced negative impact on the environment. Therefore, it is demonstrated that $\mathrm{P}$ is the determinative factor of eutrophication, from the thermodynamic viewpoint. Thus, the most desirable eutrophication control strategy is to reduce $\mathrm{P}$ input to the desired level.

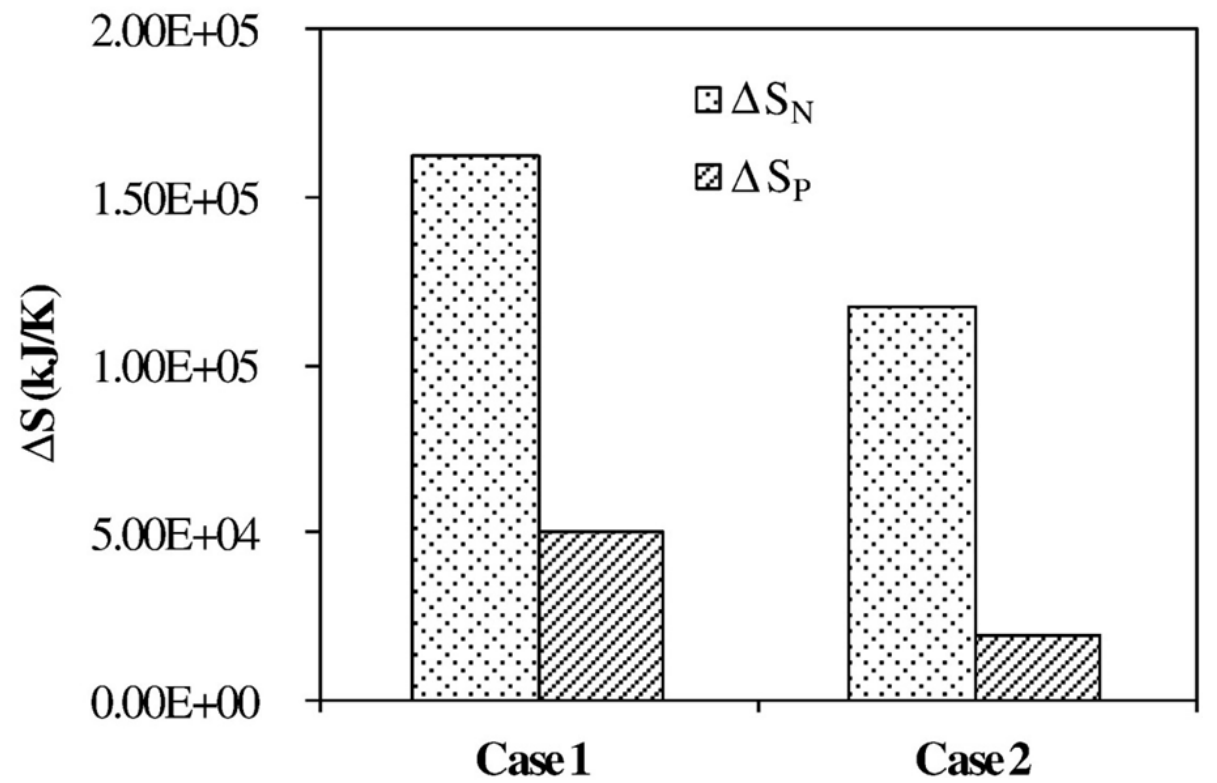

Fig. 5. Entropy production due to excess discharge of $\mathrm{TN}\left(\Delta \mathrm{S}_{\mathrm{N}}\right)$ or $\mathrm{TP}\left(\Delta \mathrm{S}_{\mathrm{P}}\right)$ for two case scenarios of an existing Class IB (Case 1) and an upgraded Class 1A (Case 2) WWTPs effluents.

Based on the above analysis, stricter $\mathrm{P}$ discharge standards may be required to reduce the risk of algal growth. Besides the national standard, every province and city may issue its own effluent discharge standard, and the local standard must be stricter than the national standards. Beijing is an example that has already issued and implemented its own local discharge standard of Water Pollutants for Municipal WWTPs (DB11/890-2012), replacing the national standard in July 2012. According to the DB11/890-2012, newly constructed/rehabilitated municipal WWTPs effluents discharge to a Class IV or V water body shall comply with the B standard, requiring TN and TP concentrations of no more than $15 \mathrm{mg} / \mathrm{L}$ and $0.3 \mathrm{mg} / \mathrm{L}$, respectively. Compared to the Class IA of GB18918-2002, the limit concentration of TP is reduced from $0.5 \mathrm{mg} / \mathrm{L}$ to $0.3 \mathrm{mg} / \mathrm{L}$. This implies a $66.7 \% \Delta S_{P}$ reduction for newly constructed/rehabilitated municipal WWTPs in Beijing. In addition, the strictest local standard for WWTPs effluents in Beijing requires TN and TP concentrations of no more than $10 \mathrm{mg} / \mathrm{L}$ and $0.2 \mathrm{mg} / \mathrm{L}$. Therefore, to satisfy the demands for high quality effluent, further advanced treatment technologies, such as membrane technology including ultrafiltration (UF), nanofiltration (NF) and reverse osmosis (RO) are desperately needed. 


\section{Conclusions}

Algal biomass production occurs via photosynthesis with associated heat energy dissipation, from the thermodynamic viewpoint. This process inevitably alters the thermodynamic state of the aquatic system, which can be evaluated by calculating $\Delta \mathrm{S}$. In the current study, by calculating the molar enthalpy of six algae strains of distinct molecular formula, the heat energy consumed for the production of a unit algal biomass was evaluated. Additionally, a proportionality relationship was established between $\Delta \mathrm{S}$ and the algal biomass with a coefficient of about $44 \mathrm{~kJ} / \mathrm{g}$. Proportionality relationships were also identified between the heat energy consumption and the mass of $\mathrm{N}$ or $\mathrm{P}$ uptake by in the algal biomass. These relationships were further validated experimentally by measuring the heat of combustion for three algae strains. Eventually, the $\Delta S$ associated with algae growth in a receiving water body due to excess nutrients discharge could be calculated for the quantitative assessment of the impact of eutrophication on the water environment. The proposed method also enabled the comparison of N-limiting and P-limiting conditions for eutrophication. Results from a case study scenario with WWTP effluent discharge to a water body indicated that the $\Delta \mathrm{S}$ due to a unit mass of $\mathrm{P}$ is 7 times of that due to $\mathrm{N}$. It can, thus, be concluded that $\mathrm{P}$ discharge control is more crucial for protecting the water environment. Further studies are needed to provide greater insight into the mechanisms underlying the direct or indirect interactions of nutrients with $\Delta \mathrm{S}$.

\section{Acknowledgements}

This work was supported by the National Natural Science Foundation of China (No. 51508448), the National Program of Water Pollution Control (No. 2013ZX07310-001), the Program for Innovative Research Team in Shaanxi Province (No. 2013KCT-13) and the collaborative research between Xi'an University of Architecture and Technology and University of Technology, Sydney (No. XAUAT-UTS-2010). The authors also thank Dr. Mawuli Dzakpasu for carefully English proofreading.

\section{Appendix A. Supplementary material}

Supplementary data related to this article can be found at http://dx.doi.org/10.1016/j.renene.2017.02.001.

\section{References}

Aoki, I., 1983. Entropy productions on the earth and other planets of the solar system. J. Phys. Soc. Jpn. 52, 1075-1078.

Aoki, I., 1987. Entropy balance in Lake Biwa. Ecol. Model. 37, 235-248.

Aoki, I., 2006a. Ecological pyramid of dissipation function and entropy production in aquatic ecosystems. Ecol. Complex. 3, 104-108.

Aoki, I., 2006b. Min-Max principle of entropy production with time in aquatic communities. Ecol. Complex. 3, 56-63.

Aoki, I., 2008. Entropy law in aquatic communities and the general entropy principle for the development of living systems. Ecol. Model. 215, 89-92. 
Atkins, P., de Paula, J., 2002. Atkins' Physical Chemistry. seventh ed. Oxford University Press, New York.

Battley, E.H., 1999. An empirical method for estimating the entropy of formation and the absolute entropy of dried microbial biomass for use in studies on the thermodynamics of microbial growth. Thermochim. Acta 326, 7-15.

Battley, E.H., 2011. A short review and an empirical method for estimating the absorbed enthalpy of formation and the absolute enthalpy of dried microbial biomass for use in studies on the thermodynamics of microbial growth. J. Therm. Anal. Calorim. 13-22.

Beal, C.M., Hebner, R.E., Webber, M.E., 2012. Thermodynamic analysis of algal biocrude production. Energy 44, 925-943.

Cai, T., Park, S.Y., Li, Y., 2013. Nutrient recovery from wastewater streams by microalgae: status and prospects. Renew. Sust. Energ. Rev. 19, 360-369.

Carey, R.O., Hochmuth, G.J., Martinez, C.J., Boyer, T.H., Dukes, M.D., Toor, G.S., Cisar, J.L., 2013. Evaluating nutrient impacts in urban watersheds: challenges and research opportunities. Environ. Pollut. 173, 138-149.

Chakrabarti, C.G., Ghosh, K., 2009. Non-equilibrium thermodynamics of ecosystems: entropic analysis of stability and diversity. Ecol. Model. 220, 1950-1956.

Chisti, Y., 2007. Biodiesel from microalgae. Biotechnol. Adv. 25, 294-306.

Conley, D.J., Paerl, H.W., Howarth, R.W., Boesch, D.F., Seitzinger, S.P., Havens, K.E., Lancelot, C., Likens, G.E., 2009. Controlling eutrophication: nitrogen and phosphorus. Science 323, 1014 1015.

Diaz-Mendez, S.E., Sierra-Grajeda, J.M.T., Hernandez-Guerrero, A., Rodriguez-Lelis, J.M., 2013. Entropy generation as an environmental impact indicator and a sample application to freshwater ecosystems eutrophication. Energy 61, 234-239.

Gallego, A., Hospido, A., Moreira, M.T., Feijoo, G., 2008. Environmental performance of wastewater treatment plants for small populations. Resour. Conserv. Recycl. 52, 931-940.

Gubelit, Y., Polyak, Y., Dembska, G., Pazikowska-Sapota, G., Zegarowski, L., Kochura, D., Krivorotov, D., Podgornaya, E., Burova, O., Maazouzi, C., 2016. Nutrient andmetal pollution of the eastern Gulf of Finland coastline: sediments, macroalgae,microbiota. Sci. Total Environ. 550, 806-819.

Hognon, C., Dupont, C., Grateau, M., Delrue, F., 2014. Comparison of steamgasification reactivity of algal and lignocellulosic biomass: influence of inorganic elements. Bioresour. Technol. 164, 347-353.

ISO, 2009. Solid Mineral Fuels-Determination of Gross Calorific Value by the Bomb Calorimetric Method and Calculation of Net Calorific Value. 1928:2009. International Standardisation Organisation, Geneva, Switzerland.

Jin, L., Zhang, G., Tian, H., 2014. Current state of sewage treatment in China. Water Res. 66, 85-98.

Lin, H., 2015. Thermodynamic entropy fluxes reflect ecosystem characteristics and succession. Ecol. Model. 298, 75-86.

Lin, Y., He, Z., Yang, Y., Stoffella, P.J., Phlips, E.J., Powell, C.A., 2008. Nitrogen versus phosphorus limitation of phytoplankton growth in Ten Mile Creek, Florida, USA. Hydrobiologia 605, 247258.

Lucia, U., 2012. Irreversibility in biophysical and biochemical engineering. Phys. A 391, 5997-6007. 
Ludovisi, A., 2004. Biotic and abiotic entropy production in lake ecosystems. Ecol. Model. 179, 145147.

Ludovisi, A., 2006. Use of thermodynamic indices as ecological indicators of the development state of lake ecosystems: specific dissipation. Ecol. Indic. 6, 30-42.

Ludovisi, A., 2012. Energy degradation and ecosystem development: theoretical framing, indicators definition and application to a test case study. Ecol. Indic. 20, 204-212.

Ludovisi, A., 2014. Effectiveness of entropy-based functions in the analysis of ecosystem state and development. Ecol. Indic. 36, 617-623.

Ludovisi, A., Pandolfi, P., Illuminata, Taticchi M., 2005. The strategy of ecosystem development: specific dissipation as an indicator of ecosystem maturity. J. Theor. Biol. 235, 33-43.

Ludovisi, A., Poletti, A., 2003. Use of thermodynamic indices as ecological indicators of the development state of lake ecosystems. 1. Entropy production indices. Ecol. Model. 159, 203-222.

Manahan, S.E., 2009. Environmental Chemistry. ninth ed. Taylor \& Francis/CRC press, Boca Raton, FL, USA.

Martyushev, L.M., Seleznev, V.D., 2006. Maximum entropy production principle in physics, chemistry and biology. Phys. Rep. 426, 1-45.

Mauersberger, P., 1996. Froma theory of local processes in aquatic ecosystems to a theory at the ecosystem scale. Sci. Total Environ. 183, 99-106.

Meysman, F.J.R., Bruers, S., 2010. Ecosystem functioning and maximum entropy production: a quantitative test of hypotheses. Philos. Trans. R. Soc. Lond. Ser. B Biol. Sci. 365, 1405-1416.

Moore, C.M.,Mills,M.M., Arrigo, K.R., Berman-Frank, I., Bopp, L., Boyd, P.W., Galbraith, E.D., Geider, R.J., Guieu, C., Jaccard, S.L., Jickells, T.D., La Roche, J., Lenton, T.M., Mahowald, N.M., Maranon, E., Marinov, I., Moore, J.K., Nakatsuka, T., Oschlies, A., Saito, M.A., Thingstad, T.F., Tsuda, A., Ulloa, O., 2013. Processes and patterns of oceanic nutrient limitation. Nat. Geosci. 6, 701-710.

Muñoz, R., Guieysse, B., 2006. Algal-bacterial processes for the treatment of hazardous contaminants: a review. Water Res. 40, 2799-2815.

Muñoz, R., Meier, L., Diaz, I., Jeison, D., 2015. A review on the state-of-the-art of physical/chemical and biological technologies for biogas upgrading. Rev. Environ. Sci. Biotechnol. 14, 727-759.

Samiei, K., Fröling, M., 2014. Sustainability assessment of biomass resource utilization based on production of entropy - case study of a bioethanol concept. Ecol. Indic. 45, 590-597.

Sansawa, H., Endo, H., 2004. Production of intracellular phytochemicals in Chlorella under heterotrophic conditions. J. Biosci. Bioeng. 98, 437-444.

Statham, P.J., 2012. Nutrients in estuaries - an overview and the potential impacts of climate change. Sci. Total Environ. 434, 213-227.

Strokal, M., Kroeze, C.,Wang,M.,Ma, L., 2017. Reducing future river export of nutrients to coastal waters of China in optimistic scenarios. Sci. Total Environ. 579, 517-528.

Svirezhev, Y.M., 2000. Thermodynamics and ecology. Ecol. Model. 132, 11-22.

von Stockar, U., Liu, J.S., 1999. Does microbial life always feed on negative entropy? Thermodynamic analysis of microbial growth. Biochim. Biophys. Acta Bioenergetics 1412, 191211.

Zamparas, M., Zacharias, I., 2014. Restoration of eutrophic freshwater by managing internal nutrient loads. A review. Sci. Total Environ. 496, 551-562. 